\title{
Thermal and economic performance of extensive green roof during typical Lebanese winter and summer days
}

\author{
Makram El Bachawati $^{1}$, Rima Manneh ${ }^{1}$, Rafik Belarbi ${ }^{2}$, and Jessica Koura ${ }^{1,2}$ \\ ${ }^{1}$ University of Balamand, Chemical Engineering Department, El Koura, North Lebanon, PO Box: 100-Tripoli, \\ Lebanon \\ ${ }^{2}$ University of La Rochelle, Laboratory of Engineering Science for Environment "LaSIE" UMR 7356 CNRS, \\ Avenue Michel Crépeau, 17042, La Rochelle Cedex 1, France
}

\begin{abstract}
The main objective of this research is to determine and compare, using real-time monitoring, the thermal performance of a Traditional Gravel Ballasted Roof (TGBR) mockup and an Extensive Green Roof (EGR) mockup during typical Lebanese winter and summer days. For this purpose, temperature profile of a TGBR mockup was experimentally assessed and compared to the one of an EGR mockup using a $70 \mathrm{~cm} \times 70 \mathrm{~cm}$ roof mockups installed on the rooftop of the Chemical Engineering Department at the University of Balamand in Lebanon. The internal temperature was measured for the different roof layers using a total of 7 cross-calibrated thermocouples while air temperature was monitored at $110 \mathrm{~cm}$ height using a waterproof temperature sensor. Temperature measurements were recorded every minute. Findings revealed that EGR protect the roof membrane from high temperature fluctuations due to thermal phenomena such as evapotranspiration and solar shading. Moreover, results confirmed that EGR mitigate the temperature fluctuations by $7.61 \%$ and $22.66 \%$ during typical Lebanese winter and summer days respectively. Outcomes of this study also verify the passive cooling effect of EGRs during hot summer days and during cold winter days. Therefore, EGRs are very efficient in countries with short winter season and long warm/sunny days such as Lebanon. From an economical perspective, EGRs are more cost effective than TGBRs (contributing to an approximate money saving of 73.72 USD during the winter season and 75.52 USD during the summer season).
\end{abstract}

Keywords: Extensive green roof, thermal comfort, economic study, Lebanon

\section{Introduction}

Vegetative Roofs (VRs) are gaining popularity due to many benefits compared to Traditional Gravel Ballasted Roofs (TGBRs). In particular, from an energetic perspective, the use of VRs can be very efficient, especially in summertime when VRs could reduce temperature fluctuations through the direct shading of plant canopy and cool the ambient air by consuming solar heat gain for transpiration and photosynthesis processes [1]. Moreover, VRs have an aesthetic appeal [2] and can mitigate noise pollution [3]. There are two main types of VRs: Intensive Green Roof (IGR) with a substrate $>20 \mathrm{~cm}$ and Extensive Green Roof (EGR) with a substrate $<20 \mathrm{~cm}$ [4].

Several researches have been conducted on the temperature regime of VRs compared to TGBRs to prove that VRs protect the roof membrane from extreme temperature fluctuations [5, 6]. Jaffal et al. (2012) studied the energy performance of VRs compared to TGBRs in a temperate oceanic climate concluding that average indoor air temperature under TGBRs and VRs differed only by $1.5^{\circ} \mathrm{C}$ in a sunny winter day, and was the same $\left(19.0^{\circ} \mathrm{C}\right)$ in a typical winter day [6]. To date, no study has yet explored in the literature the temperature profile of EGRs during typical Lebanese winter and summer days as suggested in this study.

VRs are recent technologies in Lebanon. So far, only a total of 5 VRs have been installed. VRs could be an interesting option for Lebanon, a country characterized by moderate temperatures. Such roofs could also be a plausible solution to the Lebanese energy crisis. In particular, the Lebanese electricity sector is facing major problems since the civil war (1975-1990) [7, 8]. The "Electricité du Liban" (EDL), a public institution under the control of the Ministry of Energy and Water, was and still is mandated the responsibility of the generation, transmission, and distribution of electrical energy in Lebanon [9]. Despite the major rehabilitation plan, blackouts are common all around the year in almost all the Lebanese cities [10].

This research, a first of its kind in the Middle East region, focuses on i) characterizing and analyzing the thermal performance of TGBR and EGR mockups during typical Lebanese winter and summer days and ii) stating the economical aspect of EGR in the Mediterranean context. 
Proc. of the Fifth International Conference on Advances in Civil, Structural and Environmental Engineering - ACSEE 2017. Copyright ( $)$ Institute of Research Engineers and Doctors. All rights reserved.

ISBN: 978-1-63248-122-1 doi: 10.15224/ 978-1-63248-122-1-34

\section{Material and methods}

2.1 Description of the roof mockups

A TGBR and an EGR (with a substrate depth of $16 \mathrm{~cm}$ ) roof mockups of square shape $(70 \mathrm{~cm} \times 70 \mathrm{~cm}$ ) were installed on the rooftop of the Chemical Engineering Department at the University of Balamand, Lebanon $\left(34^{\circ} 31^{\prime} \mathrm{N}, 35^{\circ} 50^{\prime} \mathrm{E}\right)$. TGBR and EGR mockups as well as their different layers are shown in Figure 1. The roofs constituents and their respective amount are the same as the ones used by El Bachawati et al. (2016) [11].

(a)

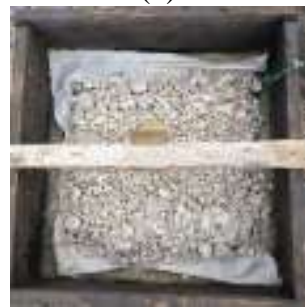

(b)

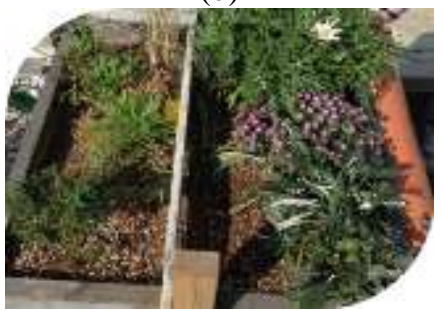

(c)

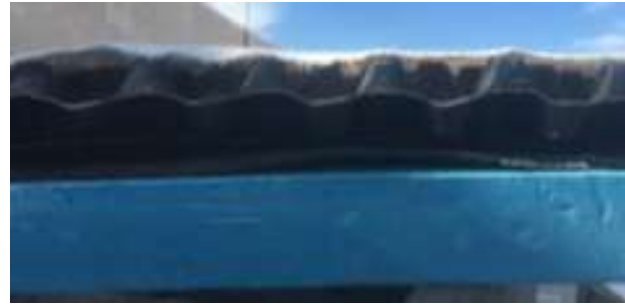

Figure 1: (a) TGBR (b) EGR16 mockups and (c) different intermediate layers installed on the chemical engineering building

The different mockups were not covered and were installed about $10 \mathrm{~m}$ above the ground level [11].

The internal temperature of TGBR and EGR16 mockups was measured for the different roof layers using a total of 7 cross-calibrated thermocouples from Mesurex-France (as shown in Figure 2), and recorded with a datalogger connected to multiplexer produced by Campbell Scientific-United States. Air temperature was monitored at $110 \mathrm{~cm}$ height using a waterproof temperature sensor ordered from Gemini Data Loggers-United Kingdom. Temperature measurements were recorded every minute.

(a)

(b)

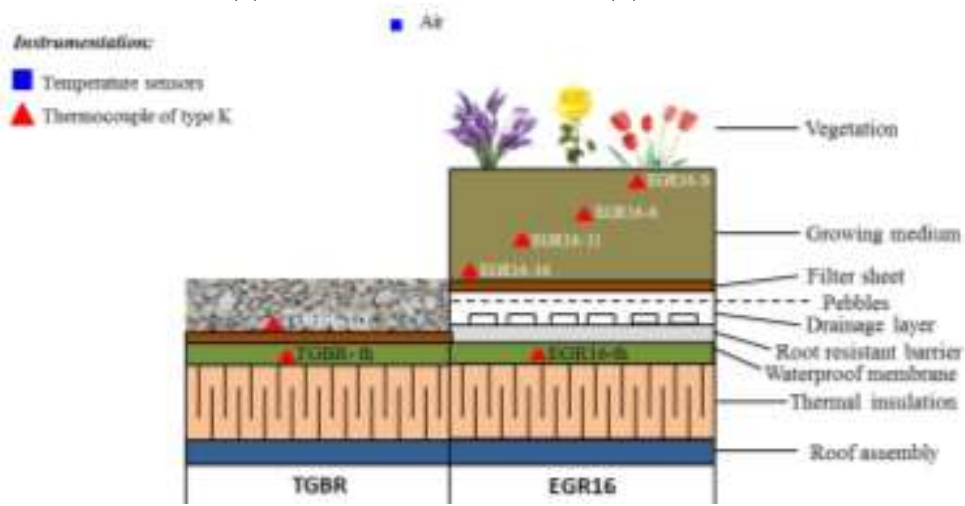

Air $\quad 110 \mathrm{~cm}$ above the surface of the mockups

TGBR-10 Between filter sheet and pebbles layer of TGBR mockup

TGBR-th Between thermal insulation and waterproof membrane of the TGBR mockup

EGR16-S At a depth of $1 \mathrm{~cm}$ in the substrate layer of EGR16 mockup (surface temperature)

EGR16-6 At a depth of $6 \mathrm{~cm}$ in the substrate layer of the EGR16 mockup

EGR16-11 At a depth of $11 \mathrm{~cm}$ in the substrate layer of the EGR16 mockup

EGR16-16 At a depth of $16 \mathrm{~cm}$ in the substrate layer of the EGR16 mockup

EGR16-th Between thermal insulation layer and waterproof membrane of EGR16 mockup

Figure 2: Location of the temperature sensors for: (a) TGBR and (b) EGR16 mockups

\subsection{Heating and Cooling Degree Day(s)}

A Degree Day (DD) is a pointer of the domestic heating/cooling consumption for a specific period of time [12]. Heating Degree Days (HDDs) and Cooling Degree Days (CDDs) were calculated using hourly temperatures. During the winter season, when the temperature falls below the comfort level (base temperature) heating is needed; while during the summer season, when the temperature rises above the comfort level, cooling is needed. The base temperature was considered $18^{\circ} \mathrm{C}$ during the winter season and $21^{\circ} \mathrm{C}$ during the summer season [11]. Equations 1.a and 1.b were used to determine HDDs and CDDs and Equation 2 was used to assess the heating/cooling cost. The occupancy factor is assumed to be $70 \%$ in residential buildings and the price of $1 \mathrm{kWh}$ of electricity is equal to 0.17 USD when provided by EDL and 0.32 USD when provided by private generators (PGs) [9, 13]. More to the point and despite the major rehabilitation plan for the Lebanese electricity sector since the civil war, electricity demand still exceeds electricity supply and blackouts can reach 13 hours per day in some cities. Therefore, Lebanese citizens still use back-up PG to ensure their electricity needs [9].
$H D D=T_{\text {base }}-T_{A}$
$C D D=T_{A}-T_{\text {base }}$
(a)
$\mathrm{HDD}=$ Heating Degree Day 
$\mathrm{CDD}=$ Cooling Degree Day

$\mathrm{T}_{\text {base }}=$ Base temperature in Celsius degree $\left(18^{\circ} \mathrm{C}\right.$ for HDD and $21^{\circ} \mathrm{C}$ for CDD $)$

$\mathrm{T}_{\mathrm{A}}=$ Average hourly temperature $\left({ }^{\circ} \mathrm{C}\right)$.

Equation 1: Degree Day formulas: (a) Heating Degree Day (b) Cooling Degree Day [14]

$$
E=D D x F \times P
$$

$\mathrm{E} \quad=$ Cost of electricity for heating or cooling (USD)

$\mathrm{DD}=$ Heating Degree Day or Cooling Degree Day

$\mathrm{F} \quad=$ Occupancy effect factor $(70 \%)$

$\mathrm{P} \quad=$ Price of electricity (EDL: US\$ 0.17/kWh; PG: US\$ 0.32/kWh)

Equation 2: Cost calculation using Degree Day

\section{Results and discussion}

\subsection{Temperature profiles}

\subsubsection{Typical Lebanese winter day}

In a typical Lebanese winter day, recorded temperatures on an hourly basis (Figure 3) were fluctuating between $6.43^{\circ} \mathrm{C}$ and $14.51^{\circ} \mathrm{C}$ for air (amplitude of $8.08^{\circ} \mathrm{C}$ ), between $6.86^{\circ} \mathrm{C}$ and $16.94^{\circ} \mathrm{C}$ under the pebbles layer of the TGBR mockup (amplitude of $10.08^{\circ} \mathrm{C}$ ), and between $8.78^{\circ} \mathrm{C}$ and $13.41^{\circ} \mathrm{C}$ under EGR 16 substrate (amplitude of $4.63^{\circ} \mathrm{C}$ ). Exceptionally, winter 2016 was warmer than usual without taking into consideration the intensity and frequency of rainfall events. A further look into the data, elaborates that the hourly temperature variation at 16 $\mathrm{cm}$ depth was lower than at 6 and $11 \mathrm{~cm}$ depths. Thus the passive cooling effect of VRs appears clearly even in a winter day. From another perspective, the bottom of the substrate layer was warmer than under the pebbles layer for the entire day especially during the night when the temperature under the pebbles layer follows the same trend of the air temperature (at $110 \mathrm{~cm}$ height) and becomes noticeably lower that at $16 \mathrm{~cm}$ depth. The values in Figure 3 were slightly lower than the ones recorded by Bass and Baskaran (2003) in Canada, where the temperature fluctuated by $25^{\circ} \mathrm{C}$ for a TGBR membrane and by $4{ }^{\circ} \mathrm{C}$ for a VR membrane on typical winter days without snow coverage [15].

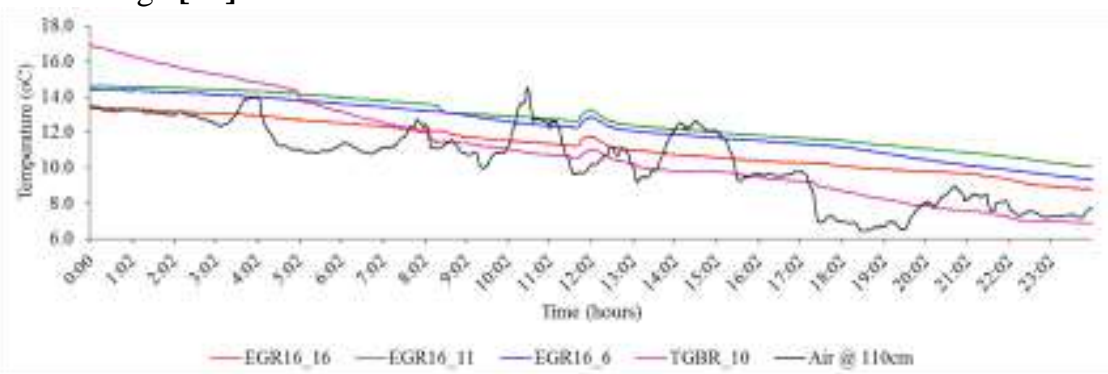

Figure 3: Temperature measurements on a typical Lebanese winter day (Feb 6, 2016).

\subsubsection{Typical Lebanese summer day}

Figure 4 displays the recorded temperature at different substrate depths, under the pebbles layer of the TGBR mockup, and in the air during typical Lebanese summer day. The hourly temperature variation at 6,11 , and 16 $\mathrm{cm}$ depths were very similar during the whole day but lower than that at $110 \mathrm{~cm}$ height. This could be explained by the fact that, at high temperature, the sun rays cross the substrate layer and reaches the bottom of the substrate layer. Moreover, the temperature under the pebbles layer was greater than that under the substrate layer. Therefore, once again the passive cooling effect of VRs appears clearly. As a result, the base roof membrane was protected from extensive temperature fluctuations which may cause serious damage if frequently occurring $[3, \mathbf{1 6}]$. The findings in this study were in agreement with the work of Bass and Baskaran (2003) and Teemusk and Mander (2009) [15, 17].

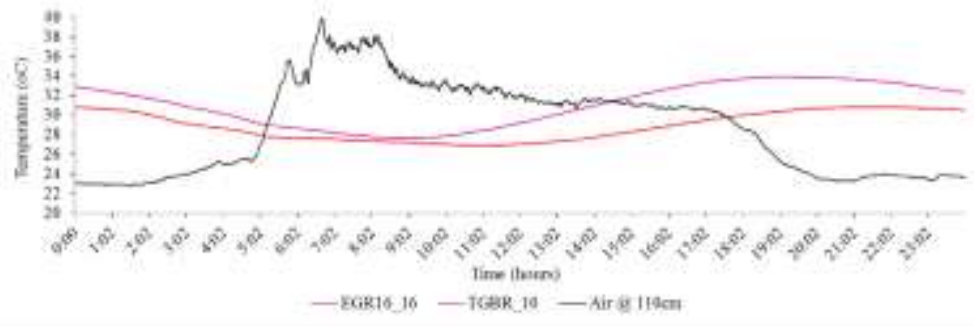

Figure 4: Temperature measurements on a typical Lebanese summer day (July 13, 2016).

\subsection{Economic study}

HDDs and CDDs were calculated based on hourly average temperatures. The outside temperature $\left(\mathrm{T}_{\mathrm{A}}\right)$ for TGBR and EGR16 was calculated based on the temperature values under the substrate and the pebbles layers 
Proc. of the Fifth International Conference on Advances in Civil, Structural and Environmental Engineering - ACSEE 2017. Copyright ( $)$ Institute of Research Engineers and Doctors. All rights reserved.

ISBN: 978-1-63248-122-1 doi: 10.15224/ 978-1-63248-122-1-34

respectively. For instance, the heat lost/gain through exterior doors, windows, and walls was neglected in this study. Table 1 indicates the HDD, the CDD, and their estimate cost for TGBR and EGR16 mockups for winter and summer seasons. For the winter season, HDD is 6.97 for TGBR mockup compared to 5.82 for EGR16 mockup while for the summer season, CDD is 7.03 for TGBR mockup compared to 5.59 for EGR16 mockup. As a result, EGR16 could save $0.24 \mathrm{US} \$ / 1 \mathrm{~m}^{2} /$ day during winter season and $0.30 \mathrm{US} \$ / 1 \mathrm{~m}^{2} /$ day during summer season compared to TGBR. From another perspective, El Bachawati et al. (2016) showed that for 45 years, TGBR and EGR16 cost $115.17 \mathrm{USD} / 1 \mathrm{~m}^{2}$ and $70.36 \mathrm{USD} / 1 \mathrm{~m}^{2}$ respectively [11].

The money savings during winter and summer seasons for TGBR and EGR16 mockups was elaborated based on the total cost (construction, maintenance, and energy) of each mockup. Generally, EGRs do not require maintenance therefore in this study the maintenance cost for EGR was assumed to be $0.25 \mathrm{US} \$ / \mathrm{m}^{2} / \mathrm{month}$ less than that of TGBR no matter what the initial maintenance cost is [18]. Table 2 displays the money savings for TGBR and EGR16 during winter and summer seasons.

For the winter season, the total cost of $200 \mathrm{~m}^{2}$ TGBR and EGR16 roofing systems is 257.50 USD and 36.34 USD respectively; for the summer season, the total cost of $200 \mathrm{~m}^{2}$ TGBR and EGR16 roofing systems is 258.62 USD and 32.07 USD respectively. As a result, in the Lebanese climate, an EGR16 could contribute to money savings of up to 73.72 USD during the winter season and 75.52 USD during the summer season.

Table 1: HDD, CDD, and their estimate cost for TGBR and EGR16 mockups during winter and summer seasons

\begin{tabular}{cccc}
\hline & & Winter season & Summer season \\
\hline \multirow{4}{*}{ TGBR } & HDD & 6.97 & 0.00 \\
& CDD & 0.00 & 7.03 \\
& $\mathrm{E}_{\mathrm{HDD}}$ & $\$ 1.44$ & $\$ 0.00$ \\
& $\mathrm{E}_{\mathrm{CDD}}$ & $\$ 0.00$ & $\$ 1.45$ \\
& & & \\
\multirow{6}{*}{ EGR16 } & $\mathrm{HDD}$ & 5.82 & 0.00 \\
& $\mathrm{CDD}$ & 0.00 & 5.59 \\
& $\mathrm{E}_{\mathrm{HDD}}$ & $\$ 1.20$ & $\$ 0.00$ \\
& $\mathrm{E}_{\mathrm{CDD}}$ & $\$ 0.00$ & $\$ 1.15$ \\
\hline
\end{tabular}

Table 2: Money savings for EGR16 compared to TGBR during winter and summer seasons

\begin{tabular}{|c|c|c|c|c|}
\hline & \multicolumn{2}{|c|}{ winter season } & \multicolumn{2}{|c|}{ summer season } \\
\hline & $\begin{array}{l}\text { TGBR } \\
\text { (USD) }\end{array}$ & $\begin{array}{l}\text { EGR16 } \\
\text { (USD) }\end{array}$ & $\begin{array}{l}\text { TGBR } \\
\text { (USD) }\end{array}$ & $\begin{array}{c}\text { EGR16 } \\
\text { (USD) }\end{array}$ \\
\hline Total roof cost $/ 1 \mathrm{~m}^{2} / 45$ years & 115.17 & 70.36 & 115.17 & 70.36 \\
\hline Total roof cost $/ 200 \mathrm{~m}^{2} / 45$ years & $23,034.00$ & $14,072.00$ & $23,034.00$ & $14,072.00$ \\
\hline Total roof cost $/ 200 \mathrm{~m}^{2} /$ season & 127.97 & 78.18 & 127.97 & 78.18 \\
\hline Energy cost $/ 200 \mathrm{~m}^{2} / 1$ day & 1.44 & 1.20 & 1.45 & 1.15 \\
\hline Energy cost $/ 200 \mathrm{~m}^{2} /$ season & 129.54 & 108.16 & 130.65 & 103.89 \\
\hline Reduction in maintenance cost $/ 1 \mathrm{~m}^{2} /$ month & 0.00 & -0.25 & 0.00 & -0.25 \\
\hline $\begin{array}{l}\text { Reduction in maintenance } \\
\text { cost } / 200 \mathrm{~m}^{2} / \text { season }\end{array}$ & 0.00 & -150.00 & 0.00 & -150.00 \\
\hline Total cost $/ 200 \mathrm{~m}^{2} /$ season & 257.50 & 36.34 & 258.62 & 32.07 \\
\hline Total cost $/ 200 \mathrm{~m}^{2} / 1$ month & 85.83 & 12.11 & 86.21 & 10.69 \\
\hline Saving $/ 200 \mathrm{~m}^{2} / 1$ month & & 73.72 & & 75.52 \\
\hline
\end{tabular}

\section{Conclusion}

During a typical Lebanese hot summer day (July 13, 2016), VRs verify the passive cooling effect by decreasing air temperature. This aspect makes VRs an effective solution for increasing the thermal comfort and dropping the cooling demand. Furthermore, VRs seem to be advantageous even in a typical Lebanese winter day (February 6, 2016), which has relatively moderate temperatures compared to Europe or North America. Therefore, the installation of VRs in a country like Lebanon could not only improve the aesthetic looks of buildings, but also help reduce the energy deficit all year round. From another perspective, VRs highly affect the heating/cooling demand of a residential building in the Lebanese climate leading to money savings of up to 73.72 USD during the winter season and 75.52 USD during the summer season.

Further work would target water management of VRs, air quality, and biodiversity of VRs in Mediterranean climate zones. A full cradle to grave Life Cycle Assessment of VRs might also give other insights. 
Proc. of the Fifth International Conference on Advances in Civil, Structural and Environmental Engineering - ACSEE 2017. Copyright (C) Institute of Research Engineers and Doctors. All rights reserved.

ISBN: 978-1-63248-122-1 doi: 10.15224/ 978-1-63248-122-1-34

\section{References}

[1] Wilmers, F. (1990). Effects of vegetation on urban climate and buildings. Energy and Buildings, 15(3), 507514. doi: http://dx.doi.org/10.1016/0378-7788(90)90028-H

[2] El Bachawati, M., Manneh, R., Belarbi, R., Dandres, T., Nassab, C., \& El Zakhem, H. (2016). Cradle-to-gate Life Cycle Assessment of traditional gravel ballasted, white reflective, and vegetative roofs: A Lebanese case study. Journal of Cleaner Production, 137, 833-842. Doi: http://dx.doi.org/10.1016/j.jclepro.2016.07.170

[3] Teemusk, A., \& Mander, Ü. (2010). Temperature regime of planted roofs compared with conventional roofing systems. Ecological Engineering, 36(1), 91-95. doi: http://dx.doi.org/10.1016/j.ecoleng.2009.09.009

[4] C.Y. Jim, S.W. Tsang, Ecological energetics of tropical intensive green roof, Energy Build. 43 (10) (2011) 2696-2704.

[5] Wong, N. H., Chen, Y., Ong, C. L., \& Sia, A. (2003). Investigation of thermal benefits of rooftop garden in the tropical environment. Building and Environment, 38(2), 261-270. doi: http://dx.doi.org/10.1016/S03601323(02)00066-5

[6] Jaffal, I., Ouldboukhitine, S., \& Belarbi, R. (2012). A comprehensive study of the impact of green roofs on building energy performance. Renewable Energy, 43, 157-164. doi: http://dx.doi.org/10.1016/j.renene.2011.12.004

[7] The World Bank. (2010). Republic of Lebanon - water sector: Public expenditure review. (Public Expenditure Review No. 52024-LB).The World Bank.

[8] Akkaya, S., Junge, N., \& Mansour, W. (November 2009). LEBANON: Social impact analysis for the electricity and water sectors. (No. 51803-LB).The World Bank.

[9] The European Union. (2012). Paving the way for the Mediterranean solar plan: Lebanon. (No. ENPI 2010/248-486).The European Union

[10] Bjerde, A., Covindassamy, A., Hamaide, M., Takahashi, M., \& Araujo, A. (January 31, 2008). Republic of Lebanon electricity sector public expenditure review. (Public Expenditure Review No. 41421-LB). The World Bank.

[11] El Bachawati, M., Manneh, R., Belarbi, R., \& El Zakhem, H. (2016). Real-time temperature monitoring for traditional gravel ballasted and extensive green roofs: A Lebanese case study. Energy and Buildings, 133, 197-205. doi: http://dx.doi.org/10.1016/j.enbuild.2016.09.056

[12] Martin, B. (2009). Degree days. Retrieved from http://www.degreedays.net/introduction\#Heating_degree_days

[13] Électricité Du Liban. (2015). Électricité du Liban (EDL). Retrieved from http://www.edl.gov.lb. Accessed on March 14, 2016.

[14] Knack, S., \& Eubank, N. (June 18, 2009). Lebanon social impact analysis - electricity and water sectors. (Policy Note No. 48993-LB). The World Bank

[15] Bass B, Baskaran B. Evaluating rooftop and vertical gardens as an adaptation strategy for urban areas. Institute for Research and Construction, NRCC- 46737, Project No. A020, CCAF Report B1046. Ottawa, Canada: National Research Council, 2003 .p.110. http://irc.nrc-cnrc.gc.ca/pubs/fulltext/ nrcc46737/nrcc46737.pdfS

[16] Djedjig, R., Bozonnet, E., \& Belarbi, R. (2013) Integration of a green envelope model in a transient building simulation program and experimental comparison. 13th Conference of International Building Performance Simulation Association, Chambéry, France, August 26-28. 47-53

[17] Teemusk, A., \& Mander, Ü. (2009). Green roof potential to reduce temperature fluctuations of a roof membrane: A case study from Estonia. Building and Environment, 44(3), 643-650. doi: http://dx.doi.org/10.1016/j.buildenv.2008.05.011

[18] Fioretti, R., Palla, A., Lanza, L. G., \& Principi, P. (2010). Green roof energy and water related performance in the mediterranean climate. Building and Environment, 45(8), 1890-1904. doi: http://dx.doi.org/10.1016/j.buildenv.2010.03.001 